\title{
Mitotic activity of thoracic duct cells in rabbits correlates with age and total lymphocyte numbers
}

\author{
Alexander V. Kuznetsov ${ }^{1}$, Ildar R. Fakhradiyev ${ }^{2}$, Ydyrys A. Almabayev ${ }^{3}$, Aigul Y. Almabayeva ${ }^{4}$ \\ ${ }^{1}$ Department of Human Anatomy, Novosibirsk State Medical University, Russia \\ ${ }^{2}$ Laboratory of Experimental Medicine, Kazakh National Medical University, Republic of Kazakhstan \\ ${ }^{3}$ Department of Clinical Anatomy, Kazakh National Medical University, Republic of Kazakhstan \\ ${ }^{4}$ Department of Human Anatomy with O.S. Medical University Astana, Republic of Kazakhstan
}

Alexander V. Kuznetsov, MD., Lecturer, Department of

Human Anatomy, Novosibirsk State Medical University,

E-mail: alexapex@yandex.ru

Krasny Prosp. 52, 630091, Novosibirsk, Russia

Citation: Kuznetsov AV, Fakhradiyev IR, Almabayev YA, Almabayeva AY. Mitotic activity of thoracic duct cells in rabbits correlates with age and total lymphocyte numbers. Cell Ther Transplant 2019; 8(1): 58-65.

\section{Summary}

The aim of this study was to assess correlations between rabbit mitotic thoracic duct (TD) cells, rabbit's age, and TD lymphocytes. The experiments were carried out in 27 intact male Chinchilla rabbits weighing 120-2.500 g (at the age of 1.5 weeks to 36 weeks). TD lymph specimens were drawn from the cisterna chyli of anaesthetised rabbits. The numbers of mitotic cells from TD per 100 cells, and absolute numbers of TD lymphocytes were counted in the Giemsa-stained cell smears by means of routine light microscope methods, and routine hemocytometric counts. We have performed statistical evaluation of the data by Microsoft Office Excel 2007 software. Correlations between the TD mitotic cell ratio, lymphocyte numbers, and animal age was estimated by Pearson's criteria. The mitotic cell number in TD lymph decreased from the age of 1.5 weeks (infant animals) to 36 weeks (young adult rabbits). Maximal mitotic activity was found in rabbits at 1.5 week of age $(23.0 \pm 0.14, \mathrm{P}=0.02)$ in comparison with appropriate indexes in rabbits at 4.5 and 13.5 weeks of age $\left(11.0 \pm 0.14^{*}, \mathrm{P}<0.05\right.$ and $6.3 \pm$ $0.08^{\star *}, \mathrm{P}<0.001$ respectively). In contrast to mitotic cell amounts, the absolute TD lymphocyte numbers were increased in older rabbits. The minimal TD; lymphocyte number in the 1.5 -week old rabbits aged was 2.8 \pm 0.03 , being significantly different $(P=0.04)$ against the lymphocyte numbers in rabbits aged 36 week $(5.9 \pm$ $0.05, \mathrm{P}=0.03$ ). Hence, strong negative correlations were found between the TD mitotic activity and age, mitotic cells and total TD lymphocyte numbers, as well as positive correlation between the TD lymphocytes and age (respectively, $\mathrm{R}^{2}=0.7, \mathrm{R}^{2}=0.96$ and $\mathrm{R}^{2}=0.8$ ) in immature rabbits (age from 1.5 weeks to 36 weeks). To our knowledge, these interrelations for TD lymph cells in the very young animals were detected for the first time. We conclude that the age-related correlation between mitotic activity and total lymphocyte amounts in TD allows presume optimal combinations of cytokines and other bioactive factors that regulate mitotic activity of thoracic duct cells with advancing age.

\section{Keywords}

Thoracic lymphatic duct, cell population, mitotic activity, age-dependent changes. 


\section{Introduction}

Proliferation of normal immune cells is a key process in immunogenesis, especially in immature organism. Multiplication and differentiation of immature and naive lymphoid cells occurs upon their contacts with foreign and own antigens, respectively, in thymus and Peyer patches as primary lymphoid organs. Transportation of lymphoid cells and their precursor proceeds via lymphatic system. E.g., both mature and immature immune cells migrating from intestines, mesenterial lymph nodes and other peripheral lymph organs are collected into the common lymph thoracic duct (TD) [1]. Further trafficking via thoracic duct to peripheral blood, and antigen-dependent selection of mature $\mathrm{T}$ - and $\mathrm{B}$ cell populations is followed by their maturation in secondary lymphoid organs and local lymphatic tissue [2, 3]. Immature lymphoid cells after entering thoracic duct, may prepare for cell division by forming a "mitotic spindle" made of microtubules and many associated proteins. However, distinct mechanisms of mitosis regulation are still unknown $[4,5]$. A proportion of thoracic duct cells is comprised by the nonlymphoid monocyte-like cells [6]. Hence, a sufficient immune population obtained from lymph may undergo expansion. This mitotic activity could be dependent on the stage of immunogenesis. Maturation of immune system in mammals proceeds just after birth, upon initial antigenic contacts.

Numerous workers focused on age-dependent changes of various crucial immune structures and appropriate regulators of cell proliferation and protection [7-11]. It should be taken into account that different antigen-presenting cells (APC), e.g., T cells, monocytes etc., may also migrate from vascular flow to peripheral and TD lymph [12].

Using bone marrow transplantation approach, homing experiments, and parabiotic mice, we have found that the hematopoietic stem and progenitor cells (HSPC) originate from the marrow and permanently migrate to different extramedullary tissues, where they reside for several days until entering the draining lymphatics, then returning to the bloodstream. The migratory pathways of HSPCs differ from those of lymphocytes. Therefore, the circulating HSPCs reach their target hematopoietic tissues, they do not require secondary lymphoid organs to recirculate [13].

There are only scarce data on mitotic activity of lymphoid cells in peripheral and central lymph of intact mammals. E.g., we have earlier shown sufficient mitotic activity of thoracic lymph duct cells in young rabbits $[14,15]$, being a further step to the recent concept of a "lymph humor/proliferation factor" [16]. Therefore, it is necessary to study age-related mitoses in TDL. The aim of the research was to assess correlations between rabbit MTDL, rabbit's age and LTDL. We emphasize that the features of LTDL morphology and their function are of particular interest, both in the aspect of postnatal development, and also in LTDL role for repopulation/ reconstitution of lymphoid tissue and lymphoid organs in physiological and pathological states (in oncological diseases in particular). In particular, the thoracic duct lymphoid population could be important for recovery of cellular and humoral immunity after intensive cytostatic treatment, e.g., radiation therapy, as initially shown by Strober [17] .
A significant proportion of white blood cells consisting of lymphocytes by $98 \%$ is permanently passing via the thoracic duct to bloodstream. Hence, any details on their cytokinetics may have implications to the production rate, circulation and fate of the lymphocytes in immune response [18]. The murine thoracic duct lymph contains hematopoietic stem and progenitor cells (HSPCs) that possess short- and longterm multi-lineage reconstitution capacity. The TD-derived HSPCs originate from bone marrow (BM), enter the blood, and move to different peripheral organs, where they reside for, at least, $36 \mathrm{hr}$ before entering draining lymphatics, then returning to the bloodstream and, eventually, to bone marrow (BM). The migrating HSPCs proliferate within extramedullary tissues and give rise to tissue-resident myeloid cells, preferentially dendritic cells. HSPCs may invade peripheral organs and foster the local production of tissue-resident innate immune cells under both steady-state conditions and in response to inflammatory signals [19].

The aim of our study was to assess correlations between rabbit mitotic thoracic duct cells, rabbit's age, and numbers of lymphocytes in thoracic duct.

\section{Materials and methods}

\section{Experimental animals}

The study was carried out in 29 male Chinchilla rabbits of different ages (1.5 to 36 weeks), weighing, respectively, 120 to $1800 \mathrm{~g}$ (Table 1). All the animals were kept during the experiment at the animal facility of B. Atchabarov Research Institute of Fundamental and Practical Medicine (Almaty, Kazakhstan), getting standard feeding and water ad libitum.

\section{Ethical Approval}

We understand the ethical principles under which the journal operates and our work complies with the animal ethics checklist as outlined in The ABC of Animal Experiments 2010 FELASA Accredited Scientists' Competence (Category C) course at Viikki Campus of the University of Helsinki www.helsinki.fi/weboodi and The Journal of Physiology and Experimental Physiology by D. Grundy, The Journal of Physiology, 593: 2547-2549, doi: 10.1113/JP270818. 5

\section{Lymph harvesting}

The invasive procedures were made following intravenous anaesthesia with calypsol-ketamine and lystenonum at the doses of $50 \mathrm{mg}$ and $10 \mathrm{mg} / \mathrm{kg}$ body weight, respectively. Infiltration of $1 \%$ novocaine solution was used as local anesthesia. Lymph was drawn from thoracic duct. Intubation of trachea and artificial lung ventilation were made in the SIMV mode. A rabbit was fixed on the back by its extremities, and intravenous anesthesia was made. Hair was removed from the frontside of abdomen followed by local anesthesia of abdominal wall. Thereafter, a midline laparotomy was performed. The longitudinal incision line was made along the projection of left kidney. The surgical wound was widened to the left, and the intestinal loops were moved medially. The left kidney with its vessels was located on the back side of the abdominal cavity. Novocaine anesthesia of perinephric cellular tissue was made. Left kidney and its vessels were released from fixation beginning from the lateral edge of the 
kidney up to the origin of the A. renalis and removed medially. The thoracic duct cistern was found dorsally from abdominal aorta according to the beginning of the A. renalis (Fig. 1). The cisternal lymph was obtained by punching with original glass micropipettes (Russian patent No 1465076, 1987) $[20,21]$. The lymph samples $(0.01 \mathrm{~mL})$ were transferred to microscopic slides. The cell smears were dried and stained according to Giemsa technique. The smears were studied by LEICA DM1000 light microscope at X400, or X1000 magnification with oil immersion. The number of mitoses per 100 cells was calculated in rabbit lymph by a routine method. Absolute number of leukocytes was calculated manually in the Bürker chamber. Their numbers were expressed as $1 \times 10^{9}$ per $1000 \mathrm{~mL}$.

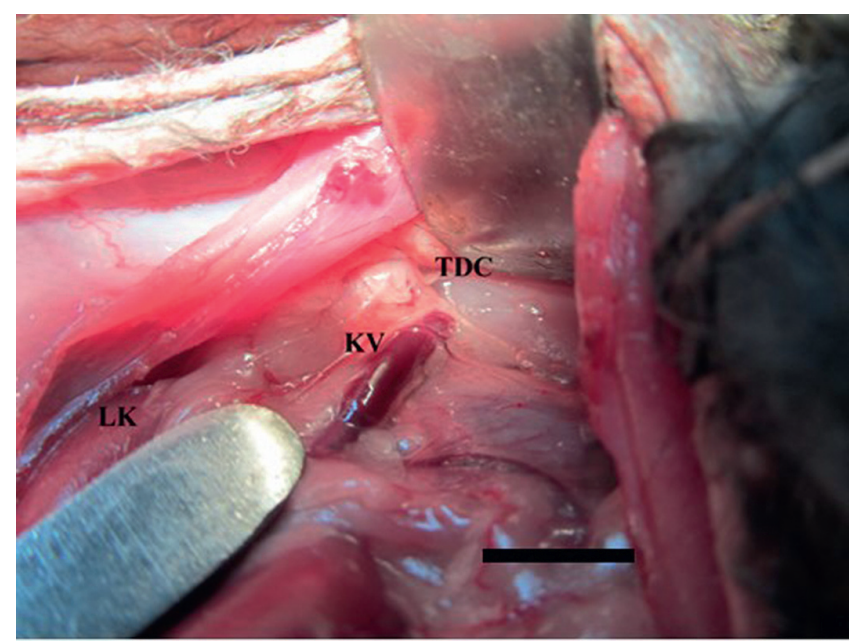

Figure 1. A surgical access to the thoracic duct cistern in rabbit. LK, left kidney; KV, left kidney vein; TDC, thoracic duct cistern (the scale bar is $1 \mathrm{~cm}$ )

\section{Statistics}

We calculated mean values, and standard deviation (SD) for the distinct groups, variance values, using Student factor (freedom degree is: $\mathrm{n}-1$ ). The obtained results were statistically calculated using confidence intervals of mean values for the groups compared. The error of average values from arithmetical average did not exceed 5\%. The differences were considered statistically significant if two-tailed $\mathrm{P}$ values of $<0.05\left(^{*}\right)$ and $\mathrm{P}<0.001\left(^{* *}\right)$. Moreover, we have calculated statistical relationships between mitotic numbers and rabbit's age, as well as between the mitotic numbers and lymphocyte numbers, using Pearson correlation quotient. All the data were expressed as the mean \pm SEM. The data were analyzed by Microsoft Office Excel 2007 software.

\section{Results}

We have revealed a number of cells at various stages of mitosis when studying thoracic lymph smears from immature rabbits (Fig. 2).

The data are expressed as mean \pm SEM. The differences between the mitotic cell ratios for various age groups and between TD cell numbers in these groups were considered statistically significant, if two-tailed $\mathrm{P}<0.05\left(^{*}\right)$ and $\mathrm{P}<0.001\left(^{* *}\right)$.

The minimal numbers of mitotic cells were observed in thoracic duct populations of mature rabbits at the age of 36 weeks.

A maximal percentage of mitoses $(23.0 \pm 0.14, \mathrm{P}=0.02, \mathrm{n}=6)$ was registered in the animals 1.5 weeks of age and remained high $(19.0 \pm 0.12, \mathrm{P}=0.01, \mathrm{n}=5)$ at the age of 2.5 weeks (body mass $240 \pm 20 \mathrm{~g}$ ). At later terms, the mitotic index progressively decreased two-fold by 4.5 weeks of age (11.0 $\pm 0.14, \mathrm{P}<0.05, \mathrm{n}=4)$, and even more at 13.5 weeks $(6.3 \pm$ $0.08, \mathrm{P}=0.04)$, when compared to initial values of 1.5 weeks (Fig. 3). With advancing age, the numbers of mitotic cells dropped down to $4.0 \pm 0.04(\mathrm{P}=0.03, \mathrm{n}=4)$ by 27 weeks, reaching a minimum of $1.0 \pm 0.01(\mathrm{P}=0.02, \mathrm{n}=6)$ by 36 weeks of age. The mitoses were virtually absent at the age of 36 weeks. Most TD cells counted in the lymph smears of mature rabbits (by 36 weeks) had the interphase morphology.

By the contrast, total numbers of thoracic duct lymphocytes increased within 36 weeks $\left(2.8 \pm 0.03 \times 10^{9}, \mathrm{P}=0.04, \mathrm{n}=6\right.$; $3.3 \pm 0.05 \times 10^{9} ; \mathrm{P}=0.05, \mathrm{n}=5 ; 4.0 \times 10^{9} \pm 0.04, \mathrm{p}=0.02, \mathrm{n}=4$; $4.7 \pm 0.04 \times 10^{9}, \mathrm{p}=0.03, \mathrm{n}=4 ; 5.4 \pm 0.03 \times 10^{9}, \mathrm{P}=0.02, \mathrm{n}=4$; $5.9 \pm 0.05 \times 10^{9}, \mathrm{P}=0.03, \mathrm{n}=6$ (at 1.5, 2.5, 4.5, 13.5, 27, 36 weeks, respectively). The total number of thoracic duct cells significantly increased in 4.5, 13.5 and 36 weeks old rabbits in comparison with the total TD cell number in 1.5 weeks old rabbits. A strong negative correlation was found between mitotic activity of thoracic duct cells and age, like as between total TD cell counts and age $\left(\mathrm{R}^{2}=0.7, \mathrm{R}^{2}=0.96\right.$ and $\mathrm{R}^{2}=0.8$ respectively) of immature rabbits at the age range of 1.5 weeks and 36 weeks (Fig. 4, 5, and 6, respectively).

A very high negative correlation $\left(\mathrm{R}^{2}=0.96\right)$ between the mitotic activity and total cell counts detected in thoracic duct lymph (Fig. 5). By contrast, a significant positive correlation $\left(\mathrm{R}^{2}=0.8\right)$, between the TD cell numbers and age was revealed (Fig. 6).

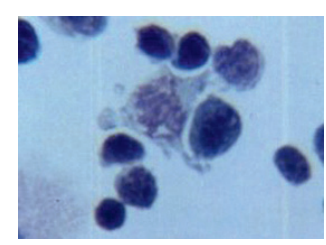

a

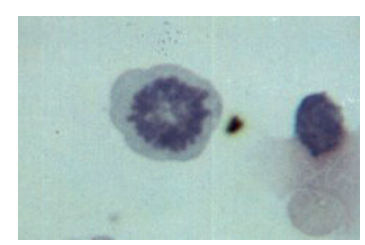

b

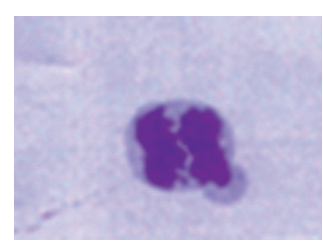

C

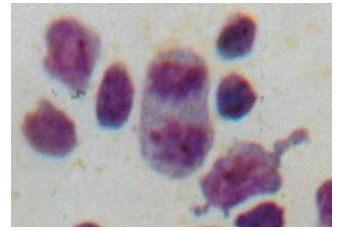

d

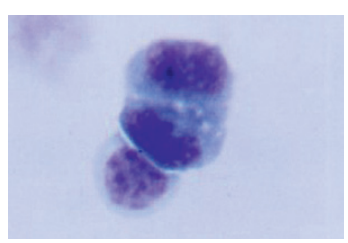

e

Figure 2. Mitotic events observed in smears of TD cells from immature rabbits (a, b, c, d) , stained by Giemsa, photomicrograph at 1000x magnification: (a), prophase; (b), metaphase; (c); early anaphase; (d), late anaphase; (e), telophase 
Table 1. Distribution of rabbits into different age groups and their parameters

\begin{tabular}{|l|l|l|l|l|l|}
\hline Groups & $\begin{array}{l}\text { Age } \\
\text { (week) }\end{array}$ & $\begin{array}{l}\text { Mean weight } \\
\text { of rabbits }(\mathbf{g})\end{array}$ & $\begin{array}{l}\text { Number of } \\
\text { rabbits }(\mathbf{n})\end{array}$ & $\begin{array}{l}\text { Mean number of mitoses } \\
\text { per 100 cells (\%) }\end{array}$ & $\begin{array}{l}\text { Mean absolute number } \\
\text { of TD cells }\end{array}$ \\
\hline 1 & 1.5 & $120 \pm 20$ & 6 & $23.0 \pm 0.14$ & $2.8 \times 10^{9} \pm 0.03$ \\
\hline 2 & 2.5 & $240 \pm 20$ & 5 & $19.0 \pm 0.12$ & $3.3 \times 10^{9} \pm 0.05$ \\
\hline 3 & 4.5 & $335 \pm 40$ & 4 & $11.0 \pm 0.14^{\star}$ & $4.0 \times 10^{9} \pm 0.04$ \\
\hline 4 & 13.5 & $540 \pm 30$ & 4 & $6.3 \pm 0.08^{\star \star}$ & $4.7 \times 10^{9} \pm 0.04$ \\
\hline 5 & 27 & $1500 \pm 200$ & 4 & $4.0 \pm 0.04$ & $5.4 \times 10^{9} \pm 0.03$ \\
\hline 6 & 36 & $1800 \pm 150$ & 6 & $1.0 \pm 0.01$ & $5.9 \times 10^{9} \pm 0.05^{\star}$ \\
\hline
\end{tabular}

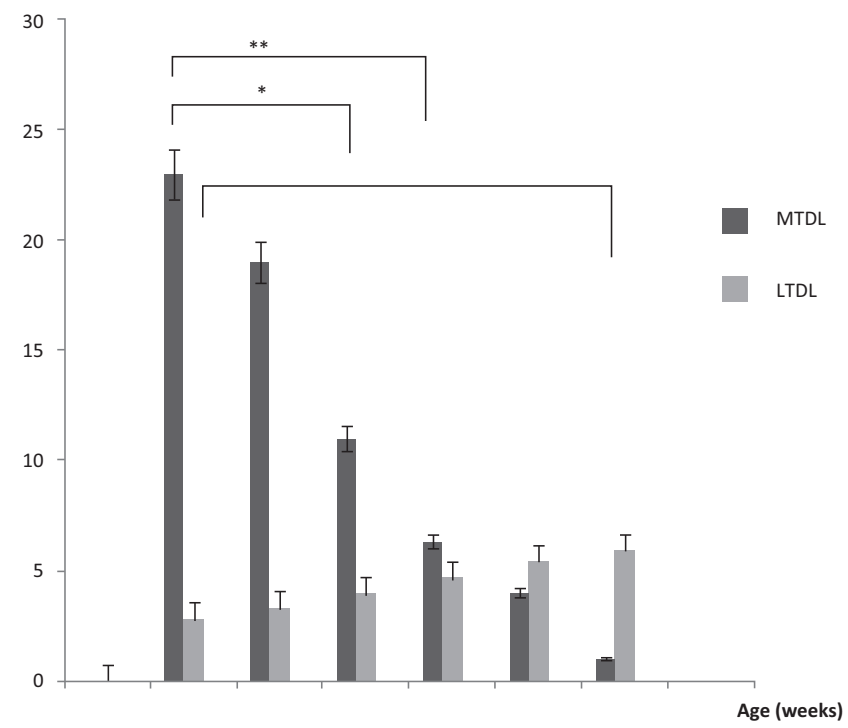

Figure 3. Changes of mitotic cell numbers in thoracic duct (MTDL) and total number of thoracic duct cells (LTDL) in rabbits aged from 1.5 to 36 weeks. Differences were considered statistically significant if two-tailed $\mathrm{P}<0.05(*), \mathrm{P}<0.001(* *)$

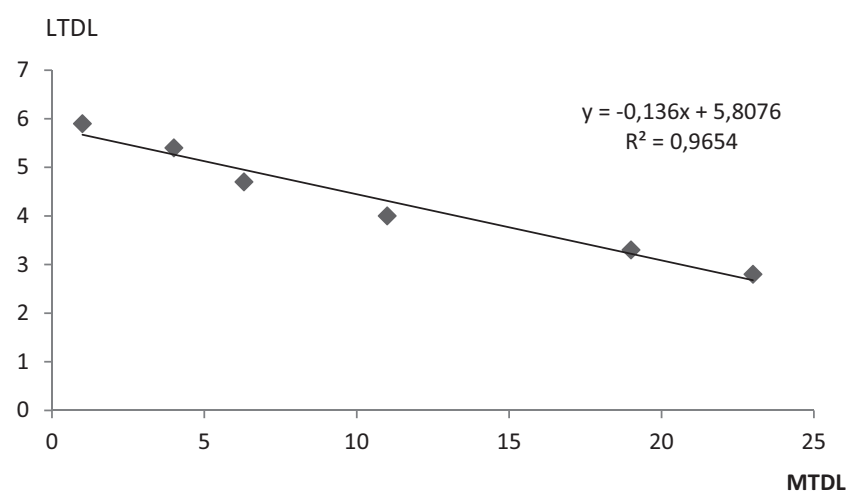

Figure 5. A strong negative correlation $\left(R^{2}=0.96\right)$ between the mitotic counts in thoracic duct cells and TD lymphocyte numbers in immature rabbits (1.5-36 weeks of age)

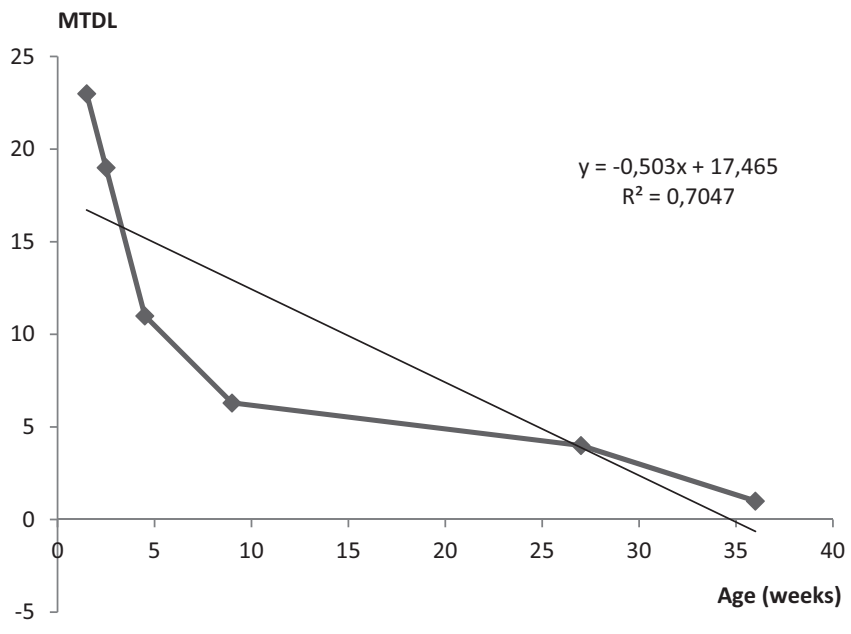

Figure 4. Pearson's correlation coefficient (very high negative correlation, $R^{2}=0.7$ ) between the mitotic thoracic duct cells (MTDL) (1x10 ${ }^{9}$ ) and age of rabbits (weeks)

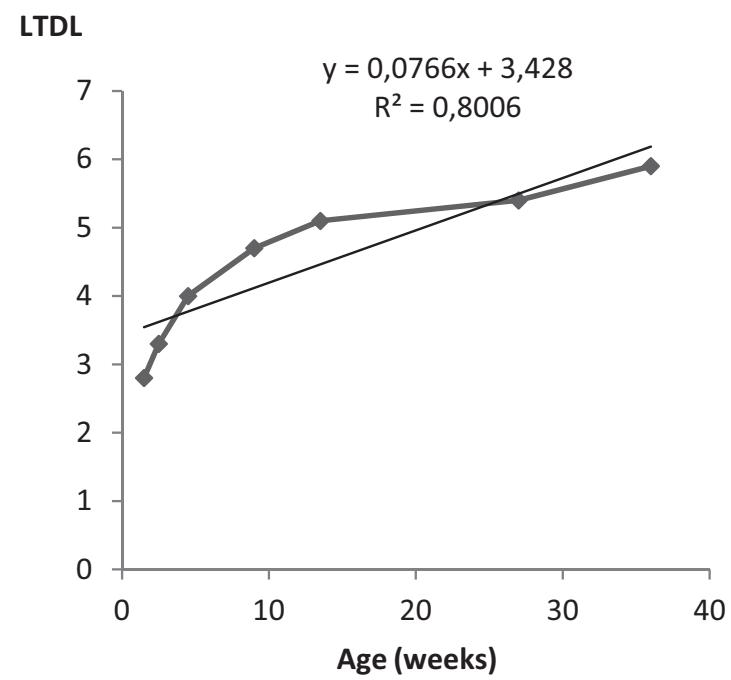

Figure 6. Significant positive correlation $\left(R^{2}=0.8\right)$ between thoracic duct cell numbers and age of rabbits upon their maturation 


\section{Discussion}

In the present study, we have for the first time demonstrated very high levels of proliferating TD cells at early maturation terms (1.5-2.5 weeks), followed by a pronounced age-dependent decrease of mitotic activity in these cell populations, as well as their correlation with increasing absolute TD cell counts in the intact immature rabbits up to 13.5 weeks of age.

Mitotic activity of lymphoid cells is the key index of physiological immune response and its maturation with time. Numerous researchers focused on age changes of various crucial immune structures and some regulators of proliferation and protection. However, most of these studies concerned the aspects of immune response in aging animals $[7,9,10]$. Meanwhile, we would like to address maturation of immune system in the very young organism, e.g., rabbit pups since the age of 10-20 days.

Our study is a part of the recent concept aiming for detection of a lymph-derived humoral factor in thoracic duct of rabbits [16]. Our current knowledge of changing TD cell numbers in rabbits allows to select the animals with optimal level or combination of cytokines or other bioactive factors in thoracic lymph duct which may have a huge impact upon the mitotic activity. A search for optimized adjuvant protocols to achieve a regulated cells proliferation is important [22].

The results of this study show that the numbers of mitotic TD cells correlate with age and LTDL of intact immature rabbits. The maximal mitotic ratio and minimal total numbers of TD cells were revealed in immature newborn rabbits, thus suggesting a huge immune potential developing in the immature rabbits.

There is also a problem of an approach to sampling TDL. However, despite numerous approaches to sampling thoracic duct lymph, researchers still propose novel techniques to this purpose. Since 1987, we have introduced an original access for sampling the thoracic duct lymph which works with no failure. Moreover, the ongoing studies in thoracic duct cannulation and lymphatic fluid collection in animals [23] and humans [24] are performed over last years, thus allowing to take lymph samples and to perform lymph drainage, e.g., for in vivo $\mathrm{T}$ cell exhaustion in human patients [25].

In conclusion, our current findings show for the first time that a correlation between the mitotic activity, absolute TD cell concentrations and rabbit's age. A very strong correlation between the mitotic cell ratio, total TD cell counts and immature rabbit's age (between 1.5 weeks-13.5 weeks) was detected. In our study the mitotic TD cell activity was compared between the intact immature male rabbits (aged 1.5-2.5-4.5 weeks), and adult animals (aged 13.5-36 weeks). The mentioned results allow us to select the age of immature rabbits with maximal numbers of mitotic cells and to perform more exact search for the suggested lymph proliferation factor. The data suggest that the age-related changes of mitotic activity suggest distinct effects of cytokines and other bioactive factors in TD cell populations, e.g., a hypothetical lymphopoietic factor revealed several decades ago [16].

We have found an evident increase in TD cell numbers in the 4.5 week-old rabbits which may result from increased lymphopoiesis at this age confirmed by high mitotic activity of TD cells. A correlation between mitotic activity, TD cell numbers and rabbit age can be used as a new experimental model applicable in different fields of biology and pharmacology. Studies in cytokines and hormone combinations as well as antigenic environment causing high cell proliferation in younger age groups of animals are worth of further studies.

The features of TD lymphocyte morphology and their function are of particular interest not only in the age aspect of postnatal development, but also in the repopulation/reconstitution of lymphoid tissue and lymphoid organs in physiological and pathological conditions, especially, in therapy of malignancies, including bone marrow transplantation techniques.

It has been known for many years, large numbers of white cells, 98 per cent of them lymphocytes, are constantly passing into the blood stream from the thoracic duct. The findings may have implications as to the generation, circulation and fate of the lymphocytes passing the thoracic duct [18].

Moreover, the thoracic duct (TD) lymph contains HSPCs (hematopoietic stem and progenitor cells) that possess short- and long-term multiline age reconstitution capacity. In murine model, the TD-derived HSPCs originate in the BM, enter the blood, and traffic to multiple peripheral organs, where they reside for at least $36 \mathrm{hr}$ before entering draining lymphatics to return to the blood and, eventually, the BM (bone marrow). Migratory HSPCs proliferate within extramedullary tissues and give rise to tissue-resident myeloid cells, preferentially dendritic cells. Thus, HSPCs can survey peripheral organs and can foster the local production of tissue-resident innate immune cells under both steadystate conditions and in response to inflammatory signals [19]. Therefore, we may suggest that, at least, a fraction of the mitotic cells found in TD of newborn rabbits may contain numerous hematopoietic precursors at different steps of differentiation which then migrate to their homing areas.

Thoracic duct (TD) provides a sufficient lymphocyte traffic: $0.65 \pm 0.21 \times 10^{6}$ lymphocytes $/ \mathrm{min}$ (the baseline lymphocyte flux) to $6.10 \pm 0.99 \times 10^{6}$ lymphocytes/min (after lymphatic pump techniques) [26], hematopoietic and progenitor cells (HSPCs) [19].

TD lymphocytes migrate into lymph nodes $[27,28,29,30$, $31,32]$ and spleen $[27,28,29,31,32]$, bone marrow [19], enter the thymus gland $[28,29]$.

It is known for decades that, at least in adult mammals, large amounts of immune cells, mostly T- and B lymphocytes, with a small portion of monocytes and dendritic cell precursors are continuously trafficking from the gut tissues and lymph nodes to the bloodstream via thoracic duct to the bloodstream [18]. Thus, our findings on the TD traffic of immature cells may have implications for production, circulation and fate of the lymphocytes. Later, our experimental techniques were confirmed by other workers [23].

Thoracic duct lymphocytes, like as bone marrow cells from normal rats are efficient in restoring the spleen marginal-zone cellularity in cyclophosphamide-treated rats, thus 
being able for renewal and proliferaiton. Thoracic duct cells passaged through an irradiated intermediate host and collected from that host's thoracic duct were also efficient at achieving marginal-zone reconstitution [30]. Moreover, many years ago, a special population of lymphokine- activated killer (LAK) cells and their precursors was found to be distributed in the thymus, bone marrow, spleen, lymph node, and thoracic duct [33]. The LAK cells are now considered a promising tool for immunotherapy of different malignancies, including leukemia and lymphoma.

Of interest are some data obtained in experiments with calf fetuses [34]. The lymphoid cell contents in thoracic duct increased ca. 50-fold from day 120 to the pre-birth levels, in parallel to expanded total pool of circulating lymphocytes. A proportion of lymphocytes bearing detectable surface immunoglobulin in fetal lymph ranged from $2.1 \%$ to $8.7 \%$. The recirculating lymphocytes from fetal calves produced strong proliferative responses when stimulated by T-cell mitogens but responded poorly to B-cell mitogens. Fetal lymphocytes also responded to stimulation by allogeneic cells and stimulated other cells to proliferate during mixed lymphocyte culture.

Interestingy, the mitotic cells in TD stream were rarely detected young adult rabbits, thus being in accordance with the data reported in other adult animal models $[23,35]$. Hence, our work has highlighted an intensive traffic of immature cell via thoracic duct at the during first weeks of life. This observation should be confirmed in other mammalian species. In general, the thoracic duct cells may be considered a significant intrinsic reserve of immune and hematopoietic cells in cytopenias induced by cytostatic treatment, e.g., during experimental bone marrow transplantation in the infants.

\section{Conclusion}

Proliferative activity of cells and total cell concentrations in thoracic lymph duct (TD) were studied in our experimental work. This study concerned mitotic activity in TD cells of newborn, very young to mature rabbits. Extremely high mitotic indexes were revealed in the 10-20 days old infant animals, thus showing high-level trafficking of immature lymphoid, and, probably, less differentiated hematopoietic cells which require further phenotypic characterization. This proliferating cell fraction may be also induced by some lymphopoietic factor(s) present in thoracic lymph. With body growth, the mitotic activity of TD cells rapidly dropped to minimal levels, along with increased cell concentrations in thoracic duct. These findings may be important in studying production, circulation and fate of TD lymphocytes in physiological and pathological states, in treatment of malignant diseases and, especially, in bone marrow transplantation based in many aspects on cellular immune therapy. Functioning of lymph ducts and differences in cellular content during infancy and at very young age may be useful for further advances in pediatric oncohematology.

\section{Competing interests}

No conflicts of interest, financial or otherwise by the authors.

\section{Acknowledgement}

This work was supported by B. Atchabarov Research Institute of Fundamental and Practical Medicine. We wish also to express our sincere thanks to Galina Igorevna Kuznetsova for help in translating the article into English.

\section{References}

1. Fanous MYZ, Phillips AJ, Windsor JA. Mesenteric lymph: the bridge to future management of critical illness. J Pancreas. 2007; 8(4):374-399.

2. Sato J, Chida K, Suda T, Sato A, Nakamura H. Migratory patterns of thoracic duct lymphocytes into bronchusassociated lymphoid tissue of immunized rats. Lung. 2000; 178:295-308

3. Ganusov VV, Auerbach J. Mathematical modeling reveals kinetics of lymphocyte recirculation in the whole organism. PLoS Comput Biol. 2014; 10(5): e1003586.

4. McIntosh JR. Mitosis. Cold Spring Harb Perspect Biol. 2016; DOI: 10.1101/cshperspect.a023218.

5. Kim HS, Fernandes G, Lee CW. Protein phosphatases involved in regulating mitosis: facts and hypotheses. Mol Cells. 2016;39(9):654-662.

6. Pugh CW, McPherson GG, Steer HW. Characterization of nonlymphoid cells derived from rat peripheral lymph. J Exp Med. 1983; 157:1758-1779.

7. Agrawal S, Ganguly S, Tran A, Sundaram P, Agrawal A. Retinoic acid treated human dendritic cells induce $\mathrm{T}$ regulatory cells via the expression of CD141 and GARP which is impaired with age. Aging (NY). 2016;8(6):1223-1235.

8. Keyes BE, Liu S, Asare A, Nailk S, Levorse J, Polak L, Lu CP, Nikolova M, Pasolli HA, Fuchs E. Impaired epidermal to dendritic $\mathrm{T}$ cell signaling slows wound repair in aged skin. Cell. 2016;167(5):1323-1338.e14.

9. Xie J, Zhang J, Wu H, Tang X, Liu J, Cheng G, Li P. The influences of age on T lymphocyte subsets in C57BL/6 mice. Saudi J Biol Sci. 2017;24(1):108-113.

10. Zhang Q, Yang K, Yangyang P, He J,Yu S, Cui Y. Age-related changes in the morphology and protein expression of the thymus of healthy yaks (Bos grunniens). Am J Vet Res. 2016; 77(6):567-574.

11. Montgomery RR. Age-related alterations in immune responses to West Nile virus infection. Clin Exp Immunol. 2017;187(1):26-34.

12. Hunter MC, Teijeira A, Halin C. T cell trafficking through lymphatic vessels. Front Immunol. 2016;7:613. doi: 10.3389/ fimmu.2016.00613.

13. Massberg S, von Andrian UH. Novel trafficking routes for hematopoietic stem and progenitor cell. Ann N Y Acad Sci. 2009;1176:87-93.

14. Kuznetsov AV. Mitoses in thoracic duct lymph of rabbits. Scientia Agriculturae. 2015; DOI: 10.15192/PSCP. SA.2015.9.2.8992. 
15. Kuznetsov AV. Dendritic cells mitoses in thoracic duct lymph of immature rabbits. Transylvanian Review. 2017; 24:3678-3681.

16. Yamashita A, Fukumoto T, Miyamoto M. Studies on lymph humoral factor. Biological characteristics of a lymphocytopoietic factor in rat thoracic duct lymph. Immunology. 1976;32: 651-656.

17. Strober S. Initiation of antibody responses by different classes of lymphocytes. III. Differences in the proliferative rates of thoracic duct lymphocytes involved in primary and secondary responses. J Immunol. 1970; 105(3):734-737.

18. Matsuno K, Ueta H, Shu Z, Xue-Dong X, Sawanobori Y, Kitazawa Y, Bin Y, Yamashita M, Shi C. The microstructure of secondary lymphoid organs that support immune cell trafficking. Arch Histol Cytol. 2010;73(1):1-21.

19. Massberg S, Schaerli P, Knezevic-Maramica I, Köllnberger M, Tubo N, Moseman EA, Huff IV, Junt T, Wagers AJ, Mazo IB, von Andrian UH. Immunosurveillance by hematopoietic progenitor cells trafficking through blood, lymph, and peripheral tissues. Cell. 2007; 131: 994-1008.

20. Kuznetsov AV. A new procedure for sampling lymph in animals. Bull Exp Biol Med. 1993; 116: 329-331 (in Russian).

21. Kuznetsov AV. Dendritic (Langerhans) cells in central lymph of rabbits. Lymphology. 2000; 33: 67-68.

22. Yin X, Xu X, Zhao Y, Wang ZJ, Wang HY, Hu ZB. Comparison of several optimization schemes for the induction and expansion of antibody-mediated high efficiency CIK (AMHE-CIK) in vitro. Zhongguo Shi Yan Xue Ye Xue Za Zhi. 2016; 24(1):191-196. (In Chinese).

23. Hardie RJ, Sheehan NK. A lateral thoracotomy approach for thoracic duct cannulation and lymphatic fluid collection in a feline model. Lab Anim. 2016;50(5):390-396.

24. Wang HW, Escott AB, Phang KL, Petrov MS, Phillips $\mathrm{AR}$, Windsor JA (). Indications, techniques, and clinical outcomes of thoracic duct interventions in patients: a forgotten literature? J Surg Res. 2016;204(1):213-227.

25. Cicciarelli JC., Iwaki Y, Terasaki PI, Guidera K, Shirahama S, Billing R, Hermes M, Cardman L, Kano T, Iwatsuki S, Koep L. Weil R, Starzl TE. Preliminary evidence of dual-marked lymphocytes in thoracic duct lymph fluid. Transplant Proc. 1980; 12(3):490-492.

26. Huff JB, Schander A, Downey HF, Hodge LM. Lymphatic pump treatment augments lymphatic flux of lymphocytes in rats. Lymphat Res Biol. 2010; 8: 183-187.

27. Sparshott SM, Sharma H, Kelly JD, Ford WL. Factors influencing the fate of 111 indium-labelled lymphocytes after transfer to syngeneic rats. J Immunol Meth. 1981; 41: 303 320 .

28. Yamashita A, Fukumoto T, Nawa Y, Kotani M, Fujii H, Era I. The generation of large pyroninophilic cells in the lymphoid tissues of rats infused with cell-free lymph. Aust J Exp Biol Med. Sci. 1975; 53: 11-26.
29. Westermann J, Smith T, Peters U, Tschernig T, Pabst R, Steinhoff G, Sparshott SM, Bell EB. Both activated and nonactivated leukocytes from the periphery continuously enter the thymic medulla of adult rats: phenotypes, sources and magnitude of traffic. Eur J Immunol. 1996; 26: 1866-1874.

30. Kumararatne DS, MacLennan IC. Cells of the marginal zone of the spleen are lymphocytes derived from recirculating precursors. Eur J Immunol. 1981; 11:865-869.

31. Everett NB, Reinhardt WO, Yoffey JM. The appearance of labeled cells in the thoracic duct lymph of the guinea pig after the administration of tritiated thymidine. Blood. 1960; 15: 82-94.

32. Ramsden CS, Drayson MT, Bell EB. Lymphocyte targeted ricin as a potential therapy for lymphoid malignancy. I. Targeting efficiency. Br J Cancer. 1991; 63: 699-704.

33. Grimm EA, Ramsey KM, Mazumder A, Wilson DJ, Djeu JY, Rosenberg SA. Lymphokine-activated killer cell phenomenon. II. Precursor phenotype is serologically distinct from peripheral $\mathrm{T}$ lymphocytes, memory cytotoxic thymus-derived lymphocytes, and natural killer cells. J Exp Med. 1983; 157: 884-897.

34. Hein WR, Shelton JN, Simpson-Morgan MW, Morris B. Traffic and proliferative responses of recirculating lymphocytes in fetal calves. Immunology. 1988; 64: 621-626.

35. Rieeke WO, Schwarz MR Protein synthesis in rat lymphocytes: radioautographic studies of availability and utilization of labeled amino acids in vivo. Blood.1964; 23: 502-516. 


\title{
Митотическая активность клеток грудного протока кроликов связана с возрастом и абсолютным количеством лимфоцитов
}

\author{
Александр В. Кузнецов ${ }^{1}$, Ильдар Р. Фахрадиев ${ }^{2}$, Ыдырыс А. Алмабаев ${ }^{3}$, Айгуль Ы. Алмабаева ${ }^{4}$ \\ ${ }^{1}$ Доктор медицинских наук, преподаватель кафедры анатомии человека НГМУ, Новосибирск, Россия \\ 2 Заведующий лабораторией экспериментальной медицины, КазНМУ им. С. Д. Асфендиярова, Республика Казахстан \\ ${ }^{3}$ Доктор медицинских наук, профессор, заведующий кафедрой клинической анатомии и оперативной хирургии \\ в КазНМУ им. С. Д. Асфендиярова, Республика Казахстан \\ ${ }^{4}$ Профессор, кафедра анатомии с оперативной хирургией, Медицинский университет Астана, г. Астана, Республика \\ Казахстан
}

\section{Резюме}

Целью нашей работы было определение возможных взаимосвязей между уровнем митозов клеток в лимфе грудного протока (ГЛП), возрастом организма и числом лимфоцитов в эксперименте (27 интактных кроликов Шиншилла, 120-2,500 гр. в возрасте 1,5-36 недель). Образцы клеток забирали из цистерны грудного протока анестезированных животных. Количество митотических клеток подсчитывали в процентах от общего количества лимфоцитов и в абсолютных значениях после учета в мазках, окрашенных по Гимза. Результаты обрабатывались статистическими методами с помощью Microsoft Office Excel 2007. Корреляция между указанными выше данными определялась с помощью критерия Пирсона. Количество митотических клеточных форм в лимфе ГЛП уменьшалось по мере увеличения возраста кроликов (от 1,5-36 недель, новорожденные и растущие особи ). Максимум митотической активности обнаружен у кроликов 1,5 недельного возраста $(23,0 \pm 0,14, \mathrm{P}=0.02)$ в сравнении с таковым у кроликов 4,5 и 13,5 недельного возраста $\left(11,0 \pm 0,14^{*}\right.$, $\mathrm{P}<0,05$ и $6,3 \pm 0,08^{* *}, \mathrm{P}<0,001$, соответственно).
Абсолютное же количество клеток лимфы в ГЛП повышалось с возрастом животных. Минимальную концентрацию клеток обнаруживали у 1,5 недельных кроликов $(2,8 \pm 0,03, \mathrm{P}=0.04)$, в сравнении с уровнями у 36-недельных кроликов $(5,9 \pm 0,05, \mathrm{P}=0,03)$. Сильная негативная корреляция найдена между митотической активностью клеток ГЛП и возрастом, а также общей клеточностью лимфы. Выявлена положительная корреляция между числом клеток в ГЛП и возрастом животных (соответственно, $\mathrm{R}^{2}=0,7$; $\mathrm{R}^{2}=0,96$ и $\mathrm{R}^{2}=0,8$ ) (диапазон возраста - от 1,5 до 36 недель). Найденная взаимосвязь между пролиферацией и числом клеток грудного протока у растущих животных обнаружена впервые. Полученные данные позволяют предположить наличие оптимальных комбинаций цитокинов и других биоактивных факторов, регулирующих митотическую активность клеток грудного протока с возрастом.

\section{Ключевые слова}

Грудной лимфатический проток, клеточная популяция, кролики, митотическая активность, возрастные изменения. 